\title{
PENGARUH HARGA DAN SALURAN DISTRIBUSI TERHADAP VOLUME PENJUALAN (STUDI PADA PABRIK TAHU ATB PADANG)
}

\author{
Syahmiral, Nazaruddin Aziz \\ Sekolah Tinggi Ilmu Ekonomi KBP \\ syahmiral.mini@gmail.com \\ nazaruddinaziz@akbpstie.ac.id
}

\begin{abstract}
The purpose of this study was to analyze the effect of prices and distribution channels partially and simultaneously on the sales volume at Padang's ATB Tofu Factory. The research method used is quantitative. The sampling technique used is the total sampling method so that from the population a sample of 32 respondents was taken, the data collection method used was a questionnaire. Data analysis techniques used are classical assumptions, multiple linear regression, $t$ test and detemination coefficient. Based on multiple regression analysis obtained $Y=5,056+0,207 X 1+0,486 X 2+e$. From the t test, it was found that the price had a positive and significant effect on the sales volume at Padang's ATB Tofu Factory and the distribution channel had a positive and significant effect on the sales volume at Padang's ATB Tofu Factory with a significant value $<0.05$. The results of the determination coefficient obtained the ability of the independent variable to explain the dependent variable of $47.3 \%$, the remaining $50.7 \%$ is explained by other variables that are not used in this study.
\end{abstract}

Keywords: Price and Distribution Channels, and Sales Volume.

\section{PENDAHULUAN}

Perkembangan usaha di Indonesia saat ini sangat pesat, salah satunya di bidang UMKM. Saat ini pemerintah sedang gencar-gencarnya memberikan kredit untuk UMKM, yaitu dengan cara menawarkan kemudahan dalam persyaratan dan prosesnya sehingga pelaku usaha bisa mengembangkan usaha merekayang memberikan kesejahteraan pada masyarakat Indonesia. Perkembangan usaha yang makin pesat, menuntut perusahaan harus bisa menghadapi persaingan tersebut. Beberapa perusahaan menawarkan produk sejenis, namun masing-masing perusahaan harus berusaha maksimal untuk menciptakan produk yang unik dan berkualitas. Selain itu perusahaan juga harus mampu memahami dan menganalisa apa yang diinginkan dan dibutuhkan oleh konsumen agar bisa bertahan dalam persaingan usaha.

Jika produk/jasa yang ditawarkan perusahaan dapat memenuhi kebutuhan dan keinginan konsumen, maka mereka akan membeli produk/jasa tersebut. 
Perusahaan juga harus dapat menentukan saluran distribusi yang tepat agar produk/jasanya sampai ke tangan konsumen dengan efektif dan efisien.

Pemasaran adalah ujung tombak sebuah perusahaan, karena melalui pemasaran perusahaan bisa mempertahankan kelangsungan hidupnya. Dalam kegiatan pemasaran terdapat beberapa hal yang mempengaruhi tingkat volume penjualan di suatu perusahaan yang disebut bauran pemasaran (marketing mix). Menurut (Pristyo, 2013) "bauran pemasaran merupakan konsep kunci dalam teori pemasaran modern". Menurut (Pristyo, 2013) "Penjualan adalah komponen yang sangat penting dalam marketing mix untuk memasarkan barang/jasa yang di gunakan, guna memberitahu serta membujuk konsumen agar membeli produknya".

Setelah perusahaan mampu menarik konsumen untuk membeli produknya, selanjutnya perusahaan tersebut mempertahankan kualitas produknya dan terus berinovasi agar konsumen tidak berpaling pada produk lain dan mengubah keputusan pembeliannya. Volume penjualan merupakan faktor terpenting dalam menentukan besarnya penerimaan oleh perusahaan.Pada saat ini pemerintah sering menetapkan kebijakan baru yang mengakibatkan naik turunnya harga bahan baku untuk persediaan produk sehingga menyulitkan perusahaan dalam hal produksi serta penetapan harga jual. Oleh karena itu perusahaan dituntut harus bisa menetapkan harga yang tepat. Persaingan harga begitu ketatmenuntut pihak pemasaran agar lebih cermat dalam menentukan harga produknya dan sesuai dengan kondisi masyarakat (Pristyo, 2013).

Menurut Karim, Sepang, \& Lumanauw (2014) "Harga sangat penting karena menentukan keuntungan dan kelangsuangan hidup perusahaan. Penentuan harga juga memiliki dampak terhadap penyesuaian strategi pemasaran yang diambil". Harga merupakan variabel bauran pemasaran yang sangat penting karena mempengaruhi besar kecilnya keuntungan perusahaan. Harga juga merupakan variabel bauran pemasaran yang sangat sensitif, penetapan harga yang dilakukan perusahaan harus bijak karena dapat mempengaruhi konsumen untuk melakukan keputusan pembelian(Nurcahyo \& Wahyuati, 2016).

Menurut Paynedalam Nurcahyo \& Wahyuati(2016) "Harga adalah harga yang dibayar, cara-cara, syarat-syarat yang mempunyai hubungan dengan penjualannya. Tjiptono (2005:86) menyatakan bahwa harga adalah satuan moneter atau ukuran lain (termasuk barang/jasa lainnya) yang ditukarkan supaya bisa mendapatkan hak kepemilikan atau penggunaan pada barang/jasa tersebut. Strategi penentuan harga berpengaruh signifikan pada perolehan nilai dari konsumen serta bisa mempengaruhi citra produk,dan bisa membentuk perilaku pelanggan sehingga bisa menentukan pembelian konsumen pada produk/jasa di perusahaan tersebut. Mengetahui tingkat volume penjualan pada sebuah perusahaan sangat perlu diperhatikan perlaku bisnis demi kelangsungan hidup pada perusahaan tersebut dimasa akan datang. Mengetahui profitabilitas perusahaan harus terlebih dahulu mengukur volume penjualan tiap periode tertentu

Angipora (2008:268) mengemukakan "Harga yaitu sejumlah uang (kemungkinan ditambah beberapa barang) yang dibutuhkan untuk memperoleh beberapa kombinasi sebuah produk/pelayanan yang ikut menyertainya. Penetapan 
harga suatu barang/jasa bagi perusahaan memberikan pengaruh sangat besarkarena harga adalah salah satu penentu terhadap permintaan pasarnya. Harga dapat mempengaruhi persaingan sebuah perusahaan serta mempengaruhi market sharenya. Harga juga akan memberikan hasil maksimal dengan memberikan sejumlah pendapatan/keuntungan bersih dan harga barang juga dapat mempengaruhi program pemasaran perusahaan, serta merupakan cara bagi produsen untuk membedakan penawaran produknya dari pesaing (Widiana dan Sinaga, 2010:59).

Banyak produsen bekerjasama dengan perantara pemasaran untuk mengirimkan produk-produknya kepasar. Penggunaan perantara akan menghasilkan efisiensi superior dalam penyediaan barang dan menyebarkannya ke pasar sasaran. Dari pandangan sistem ekonomi, peran utama dari perantara pemasaran adalah mentransformasikan beragam bahan yang dari alam dan mengolahnya menjadi bermacam-macam barang yang anggota masyarakat mau membelinya (Thamrin dan Francis, 2012:207). Manajemen pemasaraan berperanan dalam merancang saluran distribusi, yaitu siapa yang akan ditunjuk sebagai penyalur, atau berapa banyak yang bersedia untuk menjadi penyalur didaerah itu. Pada pabrik tahu ATB, saluran distribusinya adalah pedagang di pasar.Pedagang mempunyai peran sangat penting, jika mereka tidak ada, maka tahu ATB tidak akan sampai ke tangan konsumen.

Produk tahu adalah salah satu bahan makanan yang sangat banyak diminati konsumen sebagai menu utama dan juga sebagai bahan campuran makanan.Di Indonesia khususnya Kota Padang banyak terdapat pabrik tahu yang menawarkan produknya ke sejumlah pasar. Pabrik Tahu ATB harus cermat dalam menetapkan harga dan memilih saluran distribusi yang tepat agar volume penjulan terus meningkat.

Dari latar belakang diatas, maka penulis tertarik untuk mengangkat masalah ini sebagai judul skripsi yang penulis susun dan secara lengkap judul tersebut adalah "Pengaruh Harga dan Saluran Distribusi terhadap Volume Penjualan (Studi pada Pabrik Tahu ATB Padang)".

Perumusan Masalah

1. Bagaimana pengaruh harga terhadap volume penjualan pada Pabrik Tahu ATB Padang?

2. Bagaimana pengaruh saluran distribusi terhadap volume penjualan pada Pabrik Tahu ATB Padang?

\section{METODE PENELITIAN}

\section{Jenis Penelitian}

Data yang diperoleh harus bisa dibuktikan kebenarannya, tepat waktu, sesuai dan dapat memberi gambaran menyeluruh, maka jenis data yang digunakan pada penelitian ini adalah data kuantitatif. Menurut Kadek Martika \& Ni Wulandari (2016) "Data kuantitatif adalah data yang diperoleh dalam bentuk angka-angka, seperti data penjualan pada Pabrik Tahu ATB”. 


\section{Populasi dan Sampel}

Menurut Sugiyono dalam Nurcahyo \& Wahyuati (2016) "Populasi adalah wilayah generalisasi yang terdiri atas objek atau subjek yang berkualitas dan memiliki karakteristik tertentu serta telah ditetapkan peneliti untuk dipelajari kemudian ditarik kesimpulannya". Sedangkan pengertian sampel menurut Sugiyono (2008:215) adalah sebagian dari populasi yang mempunyai karakteristik sama dengan populasi.

Populasi dan sampel pada penelitian ini adalah seluruh pedagang yang menjual produk tahu ATB, yaitu sebanyak 32 (tiga puluh dua) orang pedagang.

\section{Jenis dan Sumber Data}

Jenis dan sumber data yang digunakan dalam penelitian ini adalah data primer dan data sekunder. Menurut Kadek Martika \& Ni Wulandari (2016) "Data primer merupakan data yang diperoleh secara langsung dari responden/objek yang diteliti atau ada hubungannya dengan objek yang diteliti". Cara mengumpulkan data ituadalah melalui wawancara dengan karyawan atau dengan menyebarkan kuesioner.

Data sekunder merupakan data yang telah dikumpulkan terlebih dahulu dan diperoleh dari perusahaan (diluar dari peneliti sendiri). Data sekunder yang digunakan dalam penelitian ini adalah sejarah perusahaan, visi dan misi, serta struktur organisasi perusahaan.

\section{Teknik Pengumpulan Data}

Peneliti menggumpulkan data sebagai bahan penelitian dengan menggunakan kuesioner. Menurut Sugiyono dalam Nurcahyo \& Wahyuati (2016) "Kuesioner merupakan suatu teknik pengumpulan data yang dilakukan dengan cara memberi seperangkat pertanyaan atau pernyataan tertulis kepada responden untuk kemudian dijawabnya". Cara memberikan nilai terhadap respon dari responden peneliti adalah dengan menggunakan skala linkert.

\section{Teknik Analisis Data}

\section{Uji Instrumen}

\section{Uji Validitas}

Menurut Sugiyono dalam Nurcahyo \& Wahyuati (2016) validitas adalah mengukur apa yang ingin diukur dan mempunyai ketepatan. Setiap item instrumen pertanyaan dinyatakan valid jika nilai koefisien korelasi setiap item instrumen diatas 0.3 ( $\mathrm{r}$ hitung $>0,3$ ), apabila nilai $\mathrm{r}$ hitung lebih kecil daripada nilai kritis 0,3 ( $\mathrm{r}$ hitung $<0,3$ ), maka item pertanyaan dinyatakan tidak valid.

\section{Uji Reliabilitas}

Menurut Karim et al (2014) "uji reliabilitas merupakan indeks yang menunjukan sejauh mana suatu alat pengukur bisadiandalkanataudipercaya". Instrument dikatakan reliable apabila nilai croncbatch alpha lebih besar daripada 0,6 (Nurcahyo \& Wahyuati, 2016).

\section{Uji Asumsi Klasik}

\section{Uji Normalitas}

Ghozali dalam Salindeho (2014) mengemukakan bahwa uji normalitas dilakukan sebelum mengolah data berdasarkan kepada model-model statistik parametrik, bekerja berdasarkan asumsi bahwa setiap data variabel penelitian yang akan dianalisis membentuk distribusi normal. Uji Normal Kolmogorov- 
Smirnov. Pada uji normalitas, yang dijadikan sebagai dasar dalam mengambil keputusan adalah sebagai berikut:

1. P-value $<0.05$ (data berdistribusi tidak normal),

2. $\mathrm{P}-$ value $>0.05$ (data berdistribusi normal).

\section{Uji Multikolinieritas}

Menurut Ghozali dalam Salindeho (2014) "Uji multikolonieritas bertujuan untuk menguji apakah terdapat korelasi antar variabel bebas pada model regresi". Apabila nilai Variance Inflation Factor $(V I F)<10$ dan nilai Tolerance $(T O L)>$ 0,1 artinya terbebas dari multikolineritas VIF $=1 /$ Tolerance, jika VIF $=10$ maka Tolerance $=1 / 10=0,1$ (Ghozali, 2011:106).

\section{Uji Heteroskedastisidas}

Model regresi dikatakan baik adalah jika tidak terjadi heteroskedastisitas (Ghozali, 2011:139). Dasar dalam pengambilan keputusan heteroskedastisitas adalah (Ghozali, 2011:139):

1. Jika ada pola tertentu, seperti titik-titik yang membentuk pola tertentu yang teratur (bergelombang, melebar dan kemudian menyempit) maka terjadi heteroskedastisitas.

2. Jika tidak ada pola yang jelas serta titik-titik menyebar di atas dan dibawah angka 0 pada sumbu Y maka tidak terjadi heteroskedastisitas.

\section{Uji Regresi Linear Berganda}

Analisis regresi linier berganda merupakan suatu prosedur statistik dalam menganalisis hubungan antara satu variabel atau lebih variabel independen terhadap variabel dependen (Ferdinand, 2006:295). Bentuk umum multipleregresi (regresi linier berganda) adalah sebagai berikut :

Keterangan:

$$
\mathbf{Y}=\mathbf{a}+\mathbf{b}_{1} \mathbf{X}_{1}+\mathbf{b}_{2} \mathbf{X}_{2}+\mathbf{e}
$$

$\mathrm{Y} \quad=$ Volume penjualan

a $\quad=$ Konstanta

$\mathrm{b}_{1}, \mathrm{~b}_{2}=$ Koefisien regresi dari variabel bebas;

$\mathrm{X}_{1}=$ Harga

$\mathrm{X}_{2}=$ Saluran ditsribusi

e $\quad$ Faktor pengganggu dari luar model (error).

Uji Koefisien Determinasi $\left(\mathbf{R}^{2}\right)$

Ghozali dalam Salindeho (2014) menyatakan bahwa koefisien determinasi

$\left(\mathrm{R}^{2}\right)$ digunakan untuk mengukur seberapa jauh kemampuan model dalam menerangkan variasi variabel dependen. Nilai koefisien determinasi adalah antara 0 (nol) dan 1 (satu).

\section{Uji Hipotesis (t-test)}

Uji t menunjukkan pengaruh satu variabel independen secara individual dalam menerangkan variasi variabel dependen (Ghozali dalam Salindeho, 2014). Kriteria pengujian secara parsial menggunakan tingkat level of significant $\alpha=$ 0,05 ,Jika t signifikan $>\alpha=0,05$ maka variabel bebas tidak berpengaruh signifikan terhadap variabel terikat. 


\section{HASIL DAN PEMBAHASAN \\ Hasil Uji Instrumen \\ Hasil Uji Validitas}

Berdasarkan uji validitas variabel harga, maka dapat dilihat seperti Tabel 1 sebagai berikut:

Tabel 1

Uji Validitas Harga $\left(\mathbf{X}_{1}\right)$

\begin{tabular}{|c|c|c|c|c|}
\hline No & Jumlah Pernyataan & $\begin{array}{l}\text { Corrected } \\
\text { Item-Total } \\
\text { Correlation }\end{array}$ & $\mathbf{r}_{\text {-tabel }}$ & Keterangan \\
\hline 1 & $\begin{array}{l}\text { Harga tahu pada Pabrik Tahu ATB Padang sesuai dengan kualitas } \\
\text { produk yang dimiliki. }\end{array}$ & 0,507 & 0,30 & Valid \\
\hline 2 & $\begin{array}{l}\text { Daftar harga yang dimiliki oleh Pabrik Tahu ATB Padangmemberikan } \\
\text { informasi yang lengkap tentang produk yang dimiliki. }\end{array}$ & 0,668 & 0,30 & Valid \\
\hline 3 & $\begin{array}{l}\text { Harga tahu pada Pabrik Tahu ATB Padang dapat bersaing dengan } \\
\text { harga tahu lainnya yang ada di kota padang. }\end{array}$ & 0,716 & 0,30 & Valid \\
\hline 4 & $\begin{array}{l}\text { Harga produk pesaing masih tergolong tinggi dari pada harga pada } \\
\text { Pabrik Tahu ATB Padang. }\end{array}$ & 0,646 & 0,30 & Valid \\
\hline 5 & $\begin{array}{l}\text { Pabrik Tahu ATB Padangmemberikan harga diskon dalam pembelian } \\
\text { tunai. }\end{array}$ & 0,702 & 0,30 & Valid \\
\hline 6 & $\begin{array}{l}\text { Saya melakukan pembelian pada pabrik Tahu ATB Padangkarena } \\
\text { memberikan potongan harga yang tinggi. }\end{array}$ & 0,806 & 0,30 & Valid \\
\hline 7 & $\begin{array}{l}\text { Pabrik Tahu ATB Padang memberikan bermacam cara pembayaran } \\
\text { seperti harian dan mingguan. }\end{array}$ & 0,608 & 0,30 & Valid \\
\hline 8 & $\begin{array}{l}\text { Variansi pembayaran pada Pabrik Tahu ATB Padang memberikan } \\
\text { kemudahan kepada saya dalam pembayaran. }\end{array}$ & 0,485 & 0,30 & Valid \\
\hline
\end{tabular}

Sumber: Hasil Pengolahan Data Tahun 2018.

Berdasarkan Tabel 1 dapat diketahui bahwa 8 (delapan) butir pernyataan memiliki nilai corrected item-total correlation antara 0,485-0,806 atau dengan kata lain bahwa 8 (delapan) butir pernyataan yang digunakan dalam mengukur variabel harga dinyatakan valid karena nilai corrected item-total correlation lebih besar dari nilai $r$-tabel yaitu sebesar 0,30 , sehingga semua penyataan harga dapat digunakan untuk pengujian selanjutnya.

Tabel 2

Uji Validitas Saluran Distribusi $\left(\mathbf{X}_{2}\right)$

\begin{tabular}{|c|c|c|c|c|}
\hline No & Jumlah Pernyataan & $\begin{array}{c}\text { Corrected } \\
\text { Item-Total } \\
\text { Correlation }\end{array}$ & $\mathbf{r}$-tabel $^{-}$ & Keterangan \\
\hline 1 & Pabrik Tahu ATB Padang memiliki akses yang dekat dari jalan raya. & 0,533 & 0,30 & Valid \\
\hline 2 & Pabrik Tahu ATB Padang memiliki lokasi yang luas. & 0,562 & 0,30 & Valid \\
\hline 3 & $\begin{array}{l}\text { Saya membeli tahu pada Pabrik Tahu ATB Padangkarenamemiliki } \\
\text { lingkungan yang bersih. }\end{array}$ & 0,320 & 0,30 & Valid \\
\hline 4 & $\begin{array}{l}\text { Saya membeli tahu pada Pabrik Tahu ATB Padang karena memiliki } \\
\text { lingkungan yang aman dan nyaman. }\end{array}$ & 0,373 & 0,30 & Valid \\
\hline 5 & $\begin{array}{l}\text { Pabrik Tahu ATB Padang memiliki kendaraan pribadi dalam pengiriman } \\
\text { barang. }\end{array}$ & 0,583 & 0,30 & Valid \\
\hline 6 & $\begin{array}{l}\text { Pabrik Tahu ATB Padang memiliki lebih dari satu unit kendaraan sebagai } \\
\text { sarana alat tranpostasi untuk pengiriman barang. }\end{array}$ & 0,480 & 0,30 & Valid \\
\hline
\end{tabular}

Sumber: Hasil Pengolahan Data Tahun 2018.

Berdasarkan Tabel 2 dapat diketahui bahwa 6 (enam) butir pernyataan memiliki nilai corrected item-total correlation antara 0,320 - 0,583 atau dengan kata lain bahwa 6 (enam) butir pernyataan yang digunakan dalam mengukur 
variabel saluran distribusi memiliki nilai corrected item-total correlation lebih besar dari nilai $\mathrm{r}_{\text {-tabel }}$ yaitu sebesar 0,30 , sehingga semua penyataan saluran distribusi dapat digunakan untuk pengujian selanjutnya.

\section{Tabel 3}

Uji Validitas Volume Penjualan (Y)

\begin{tabular}{|c|c|c|c|c|}
\hline No & Jumlah Pernyataan & $\begin{array}{l}\text { Corrected Item- } \\
\text { Total Correlation }\end{array}$ & $\mathbf{r}-$ tabel & Keterangan \\
\hline 1 & Pabrik Tahu ATB Padang memiliki target penjualan tiap harinya. & 0,556 & 0,30 & Valid \\
\hline 2 & $\begin{array}{l}\text { Volume penjualan pada Pabrik Tahu ATB Padang mengalami tidak } \\
\text { stabil. }\end{array}$ & 0,386 & 0,30 & Valid \\
\hline 3 & $\begin{array}{l}\text { Pabrik Tahu ATB Padang meningkatkan produksi untuk } \\
\text { meningkatkan laba yang diinginkan. }\end{array}$ & 0,687 & 0,30 & Valid \\
\hline 4 & $\begin{array}{l}\text { Laba yang didapatkan oleh Pabrik Tahu ATB Padang mengalami } \\
\text { tidak stabil. }\end{array}$ & 0,514 & 0,30 & Valid \\
\hline 5 & $\begin{array}{l}\text { Pabrik Tahu ATB Padang memasok produknya ke pasar-pasar yang } \\
\text { ada di kota Padang maupun di luar kota Padang untuk menunjang } \\
\text { pertumbuhan perusahaan. }\end{array}$ & 0,631 & 0,30 & Valid \\
\hline 6 & $\begin{array}{l}\text { Pertumbuhan Pabrik Tahu ATB Padang tumbuh dengan pesat karena } \\
\text { permintaan konsumen semakin meningkat. }\end{array}$ & 0,499 & 0,30 & Valid \\
\hline
\end{tabular}

Sumber: Hasil Pengolahan Data Tahun 2018.

Berdasarkan Tabel 3 dapat diketahui bahwa 6 (enam) butir pernyataan memiliki nilai corrected item-total correlation antara 0,386-0,687 atau dengan kata lain bahwa 6 (enam) butir pernyataan yang digunakan dalam mengukur variabel volume penjualan dinyatakan valid karena nilai corrected item-total correlationlebih besar dari nilai $\mathrm{r}_{\text {-tabel }}$ yaitu sebesar 0,30. Dengan demikian dapat disimpulkan bahwa semua pernyataan dari variabel volume penjualan dinyatakan valid.

\section{Hasil Uji Reliabilitas}

Berdasarkan uji reliabilitas yang dilakukan pada variabel harga $\left(\mathrm{X}_{1}\right)$, saluran distribusi $\left(\mathrm{X}_{2}\right)$ dan volume penjualan $(\mathrm{Y})$ dapat dilihat pada Tabel 4 dibawah ini:

\section{Tabel 4}

Uji Reliabilitas

\begin{tabular}{lccc}
\hline \multicolumn{1}{c}{ Variabel } & Cronbach's Alpha & Cronbach's Alpha Standar & Keterangan \\
\hline Harga $\left(\mathrm{X}_{1}\right)$ & 0,878 & 0,60 & Reliabel \\
Saluran Distribusi $\left(\mathrm{X}_{2}\right)$ & 0,732 & 0,60 & Reliabel \\
Volume Penjualan $(\mathrm{Y})$ & 0,787 & 0,60 & Reliabel \\
\hline
\end{tabular}

Sumber: Hasil Pengolahan Data Tahun 2018.

Dari Tabel 4 dapat diambil kesimpulan bahwa dari uji reliabilitas yang dihasilkan nilai Cronbach's Alpha untuk variabel harga $\left(\mathrm{X}_{1}\right)$, saluran distribusi $\left(\mathrm{X}_{2}\right)$ dan volume penjualan (Y) dinyatakan reliabel karena nilai Cronbach's Alpha yang dihasilkan lebih dari 0,60 sehingga item-item pernyataan termasuk dalam kategori handal dan variabel tersebut dapat digunakan sebagai alat ukur dalam penelitian ini. 


\section{Uji Asumsi Klasik}

\section{Uji Normalitas}

Berdasarkan hasil penelitian uji normalitas pada tabel 5 adalah sebagai berikut ini:

Tabel 5

Uji Normalitas

One-Sample Kolmogorov-Smirnov Test

\begin{tabular}{llrr}
\hline & & Harga & Saluran_Distribusi \\
\hline $\mathrm{N}$ & & 32 & 32 \\
\multirow{2}{*}{ Normal Parameters } & Mean & 34,28 & 23,44 \\
& Std. Deviation & 3,674 & 2,552 \\
& Absolute &, 157 &, 150 \\
Most Extreme Differences & Positive &, 112 &, 095 \\
& Negative &,- 157 &,- 150 \\
Kolmogorov-Smirnov Z & &, 888 &, 847 \\
Asymp. Sig. (2-tailed) & &, 409 &, 470 \\
\hline
\end{tabular}

a. Test distribution is Normal.

b. Calculated from data.

Sumber: Hasil Pengolahan Data Tahun 2018.

Berdasarkan pada Tabel 5 hasil uji normalitas yang dilakukan di atas memiliki nilai Kolmogorov-Smimovvariabel harga sebesar 0,888 dan nilai signifikan 0,409 sedangkan variabel saluran distribusi memilik nilai KolmogorovSmimov sebesar 0,847 dan nilai signifikan 0,470. Dapat disimpulkan bahwa data berdistribusi dengan normal karena nilai signifikan yang dihasilkan lebih besar dari 0,05 .

\section{Uji Multikolonieritas}

Berdasarkan hasil penelitian uji multikolonieritas pada tabel 6 adalah sebagai berikut ini:

\section{Tabel 6}

Uji Multikolinearitas

\begin{tabular}{|c|c|c|c|c|}
\hline \multirow{2}{*}{ No. } & \multirow{2}{*}{ Variabel } & \multicolumn{2}{|c|}{ Collinearity Statistics } & \multirow{2}{*}{ Keterangan } \\
\hline & & Tolerance & VIF & \\
\hline 1 & & 0,879 & 1,138 & $\begin{array}{c}\text { Tidak Terjadi } \\
\text { Multikolinieritas }\end{array}$ \\
\hline 2 & Saluran Distribusi & 0,879 & 1,138 & $\begin{array}{c}\text { Tidak Terjadi } \\
\text { Multikolinieritas }\end{array}$ \\
\hline
\end{tabular}

Berdasarkan tabel 6 di atas dapat diketahui bahwa tolerance value untuk masing-masing variabel lebih besar dari 0,10 sedangkan nilai Variance Inflation Factor (VIF) untuk masing-masing variabel lebih kecildari 10. Dengan demikian dapat disimpulkan model yang digunakan dalam penelitian ini tidak mengandung gangguan multikolinieritas.

\section{Uji Heteroskedastisitas}

Berdasarkan hasil penelitian uji heterokedasitisitas pada Tabel 7 adalah sebagai berikut ini: 


\section{Tabel 7}

Uji Heterokedasitisitas

\begin{tabular}{|c|c|c|c|}
\hline No. & Variabel & Sig & Keterangan \\
\hline 1 & Harga & 0,216 & $\begin{array}{c}\text { Tidak Terjadi Gejala } \\
\text { Heterokesdatisitas }\end{array}$ \\
\hline 2 & $\begin{array}{l}\text { Saluran } \\
\text { Distribusi }\end{array}$ & 0,923 & $\begin{array}{c}\text { Tidak Terjadi Gejala } \\
\text { Heterokesdatisitas }\end{array}$ \\
\hline
\end{tabular}

Berdasarkan pada Tabel 7 dapat diketahui bahwa nilai signifikan variabel harga dan saluran distribusi memiliki nilai signifikan $>0,05$, hal ini berarti tidak terjadi gejala heterokesdatisitas.

\section{Uji Regresi Linear Berganda}

Berdasarkan uji regresi linera berganda yang dilakukan dapat dilihat pada Tabel 8 di bawah ini:

Tabel. 8

Hasil Uji Regresi Linear Berganda

Coefficients $^{\mathrm{a}}$

\begin{tabular}{|c|c|c|c|c|c|}
\hline \multirow[t]{2}{*}{ Model } & \multicolumn{2}{|c|}{ Unstandardized Coefficients } & \multirow{2}{*}{$\begin{array}{c}\text { Standardized } \\
\text { Coefficients } \\
\text { Beta } \\
\end{array}$} & \multirow[t]{2}{*}{$\mathrm{T}$} & \multirow[t]{2}{*}{ Sig. } \\
\hline & B & Std. Error & & & \\
\hline (Constant) & 5,056 & 3,455 & & 1,463 & 154 \\
\hline 1 Harga & 207 & ,089 & ,326 & 2,341 & ,026 \\
\hline Saluran_Distribusi & ,486 & , 128 &, 530 & 3,812 &, 001 \\
\hline
\end{tabular}

a. Dependent Variable: Volume_Penjualan

Sumber: Hasil Pengolahan Data Tahun 2018.

Berdasarkan analisis data dengan menggunakan program SPSS 20 for windows, maka diperoleh hasil persamaan regresi sebagai berikut:

$\mathrm{Y}=5,056+0,207 \mathrm{X}_{1}+0,486 \mathrm{X}_{2}+\mathrm{e}$

1) Nilai konstanta adalah $=5,056$, artinya jika tidak terjadi perubahan variabelharga dan saluran distribusi (nilai $X_{1}$ dan $X_{2}$ adalah 0), maka volume penjualan pada Pabrik Tahu ATB Padang tetap sebesar 5,056 satuan.

2) Nilai koefisien regresi harga adalah $=0,207$, artinya jika variabel harga $\left(\mathrm{X}_{1}\right)$ meningkat sebesar 1 (satuan) dengan asumsi variabel saluran distribusi $\left(\mathrm{X}_{2}\right)$ dan konstanta (a) adalah 0 (nol), makavolume penjualan pada Pabrik Tahu ATB Padang meningkat sebesar 0,207 satuan.

3) Nilai koefisien regresi saluran distribusi adalah $=0,486$ artinya jika variabel saluran distribusi $\left(\mathrm{X}_{2}\right)$ meningkat sebesar 1 (satuan) dengan asumsi variabel harga $\left(\mathrm{X}_{1}\right)$ dan konstanta (a) adalah 0 (nol), maka volume penjualan pada Pabrik Tahu ATB Padang meningkat sebesar 0,486 satuan. 


\section{Uji Hipotesis (t-test)}

Berdasarkan uji t yang dilakukan dapat dilihat pada Tabel 9 dibawah ini:

\section{Tabel 9}

Hasil Uji t

Coefficients $^{\mathrm{a}}$

\begin{tabular}{llrrrrr}
\hline Model & \multicolumn{2}{c}{ Unstandardized Coefficients } & $\begin{array}{c}\text { Standardized } \\
\text { Coefficients } \\
\text { Beta }\end{array}$ & T & Sig. \\
& B & Std. Error & 3,455 & & 1,463 &, 154 \\
\hline (Constant) & 5,056 &, 089 &, 326 & 2,341 &, 026 \\
1 Harga &, 207 &, 486 &, 128 &, 530 & 3,812 &, 001 \\
\hline
\end{tabular}

a. Dependent Variable: Volume_Penjualan

Sumber: Hasil Pengolahan Data Tahun 2018.

Variabel harga $\left(\mathrm{X}_{1}\right)$ berpengaruh secara positif dan signifikan terhadap volume penjualan pada Pabrik Tahu ATB Padangdengan nilai $t_{\text {hitung }}$ sebesar 2,341 sedangkan nilai signifikan $<0,05$, maka Ho ditolak dan $\mathrm{H}_{1}$ diterima. Variabel saluran distribusi $\left(\mathrm{X}_{2}\right)$ berpengaruh secara positif dan signifikan terhadap volume penjualan pada Pabrik Tahu ATB Padang dengan nilai $t_{\text {hitungsebesar } 3,812}$ sedangkan nilai signifikan $<0,05$, maka Ho ditolak dan $\mathrm{H}_{2}$ diterima.

\section{Uji Koefisien Determinasi $\left(\mathbf{R}^{2}\right)$}

Berdasarkan uji koefisien determinasi yang dilakukan maka dapat dilihat pada Tabel 10 berikut ini:

Tabel 10

Hasil Uji Koefisien Determinasi Model Summary

\begin{tabular}{lrrrrrrrrr}
\hline Model & $\mathrm{R}$ & $\mathrm{R}$ & Adjusted & \multicolumn{2}{c}{ Std. Error } & \multicolumn{4}{c}{ Change Statistics } \\
\end{tabular}

a. Predictors: (Constant), Saluran_Distribusi, Harga

Sumber: Hasil Pengolahan Data Tahun 2018.

Berdasarkan Tabel 4.19 diketahui bahwa nilai koefisien determinasi terdapat pada nilai Adjusted RSquare dengan sebesar 0,473.Hal ini berarti sumbangan variabel bebas dalam menjelaskan variabel terikatadalah sebesar $47,3 \%$ sisanya $50,7 \%$ dijelaskan oleh variabel lain yang tidak dibahas dalam penelitian ini seperti kondisi dan kemampuan penjual, kondisi pasar, modal dan kondisi organisasi perusahaan.

\section{PEMBAHASAN HASIL PENELITIAN}

\section{1) Pengaruh Variabel Harga terhadap Volume Penjualan.}

Dari hasil analisis uji hipotesa pada tingkat kepercayaan $\alpha=5 \%$ terbukti bahwa variabel harga $\left(\mathrm{X}_{1}\right)$ berpengaruh positif dan signifikan terhadap volume penjualan pada Pabrik Tahu ATB Padangdengan nilai $t_{\text {hitung sebesar 2,341 }}$ sedangkan nilai signifikan $<0,05$.Berdasarkan hasil penelitian tersebut disimpulkan bahwavolume penjualan pada Pabrik Tahu ATB Padang menjadi meningkat disebabkan karena harga yang ditawarkan kepada konsumen telah sesuai dengan daya beli konsumen di Kota Padang. Selain itu harga tahu pada 
Pabrik Tahu ATB Padang juga dapat bersaing dengan harga tahu yang diproduksi oleh pabrik lain yang ada di Kota Padang. Pemberian pilihan cara pembayaran dalam bentuk cicilan bagi konsumen yang telah lama berlangganan dengan penetapan harga yang baik dapat meningkatkan volume penjualan pada Pabrik Tahu ATB Padang.

Hasil penelitian ini sama dengan penelitianSalindeho, Hanny Aristanto (2014) yang menjelaskan bahwa faktor harga berpengaruh secara positif dan signifikan terhadap peningkatan volume penjualan pada PT. Frastata Buana, Tbk. Penelitian Selanjutnya penelitian yang dilakukan oleh Melvin Pristyo (2013) menemukan bahwa faktor harga berpengaruh secara positif dan signifikan terhadap volume penjualan pada UD. Eka Jaya di Surabaya. Sedangkan menurut Widiana dan Sinaga (2010:59) harga adalah sejumlah uang yang dibayarkan untuk mendapatkan sejumlah komblinasi dari produk dan pelayanannya.

\section{2) Pengaruh Variabel Saluran Distribusi terhadapVolume Penjualan.}

Dari hasil analisis uji hipotesa pada tingkat kepercayaan $\alpha=5 \%$ terbukti bahwa variabel saluran distribusi $\left(\mathrm{X}_{2}\right)$ berpengaruh positif dan signifikan terhadap volume penjualan pada Pabrik Tahu ATB Padang dengan nilai $t_{\text {hitungsebesar } 3,812}$ sedangkan nilai signifikan $<0,05$. Berdasarkan hasil tersebut dapat disimpulkan bahwa volume penjualan pada Pabrik Tahu ATB Padang menjadi meningkat disebabkan karena saluran distribusi yang dimiliki oleh Pabrik Tahu ATB Padang salah satunya pada lingkungan yang dimiliki oleh Pabrik Tahu ATB Padang terlihat bersih sehingga konsumen tersebut tertarik untuk membeli tahu pada Pabrik Tahu ATB Padang. Lingkungan yang bersih dapat mencerminkan kebersihan produk yang dijual selain itu juga memiliki lokasi yang mudah diakses dapat menarik perhatian konsumen untuk melakukan pembelian tahu pada pabrik Tahu ATB Padang.Pabrik Tahu ATB Padang juga dapat mengantarkan tahu yang dipesan oleh konsumen ke lokasi yang diinginkan, karenasaluran distribusi merupakan kegiatan pemasaran yang berfungsi untuk mempelancar dan mempermudah penyampaian barang/jasa dari produsen kepada konsumen.

Hasil penelitian ini sama dengan penelitian Salindeho, Hanny Aristanto (2014) yang menemukan bahwa saluran distribusi berpengaruh secara positif dan signifikan terhadap volume penjualan pada PT. Frastata Buana, Tbk. Selain itu penelitian Damas wahyu nugroho (2015) juga menemukan bahwa saluran distribusi berpengaruh secara positif dan signifikan secara langsung terhadap volume penjualan pada Percetakan Buku CV. Bima Jaya Di Surakarta. Sedangkan Kotler dan Armstrong (2008:508) menjelaskan saluran distribusi adalah sebagai himpunan perusahaan dan perorangan yang mengambil alih hak atau membantu mengalihkan hak atas barang atau jasa tersebut berpindah dari produsen ke konsumen.

\section{PENUTUP}

\section{Kesimpulan}

1. Variabel harga berpengaruh secara positif dan signifikan terhadap volume penjualan pada Pabrik Tahu ATB Padang.

2. Variabel saluran distribusi berpengaruh secara positif dan signifikan terhadap volume penjualan pada Pabrik Tahu ATB Padang. 


\section{UCAPAN TERIMA KASIH}

Penulis mengucapkan terimakasih kepada Bapak Febryandhie Ananda, SE, M.Si, selaku ketua STIE KBP Padang, Ibuk Febsri Susanti, SEI, MM selaku ketua program studi manajemen, Bapak Nazarudin Azis, SE,MM, selaku pembimbing skripsi, Bapak Irdha Yusra, SE, M.Sc, selaku pembimbing akademik, dan Ibuk Srilenayati, S.pd, selaku pemilik pabik tahu ATB Kota Padang yang telah memberikan kesempatan untuk melakukan penelitian serta memberikan data-data yang penulis gunakan dalam penelitian ini.

\section{DAFTAR PUSTAKA}

Andika, A., \& Susanti, F. (2018). Pengaruh Marketing Mix Terhadap Keputusan Pembelian Parfum di Azzwars Parfum Lubeg Padang. https://doi.org/10.31227/osf.io/upgc3

Aziz, N. (2019). Pengaruh Strategi Promosi Terhadap Keputusan Pembelian Yang Dimediasi Oleh Minat Beli Pada Konsumen Restoran KFC Cabang Khatib Sulaiman Padang. https://doi.org/10.17605/OSF.IO/V92TS

Aziz, N. (2019). Analisis Pengaruh Kualitas Produk, Harga, Promosi Terhadap Keputusan Pembelian Air Minum Dalam Kemasan (AMDK) Merek Aicos Produksi Pt. Bumi Sarimas Indonesia. https://doi.org/10.17605/OSF.IO/8XKYB

F., \& Afriyeni, A. (2019). Aktivitas Pemasaran Produk Tabungan Pada PT. Bank Pembangunan Daerah (BPD) Sumatera Barat Cabang Utama Padang. https://doi.org/10.31219/osf.io/tf2bz

Hidayati, R. R., \& Marlius, D. (2018). Aktivitas Promosi Dalam Meningkatkan Dana Pihak Ketiga Pada PT. Bank Perkreditan Rakyat (BPR) Batang Kapas Pesisir Selatan. https://doi.org/10.31227/osf.io/8dgqn

Jamarnis, S., \& Susanti, F. (2019). Pengaruh Harga Dan Periklanan Melalui Internet Terhadap Keputusan Pembelian Produk Sabun Merek Lux Pada Mahasiswa STIE “KBP” Padang. https://doi.org/10.31227/osf.io/xz3d8

Karim, D., Sepang, J. L., \& Lumanauw, B. (2014). Marketing Mix Pengaruhnya Terhadap Volume Penjualan Pada Pt. Manado Sejati Perkasa Group. Jurnal Emba, 2(1), 421-430.

Marlius, D. (2017). Keputusan Pembelian Berdasarkan Faktor Psikologis Dan Bauran Pemasaran Pada PT. Intercom Mobilindo Padang. Jurnal Pundi. Volume 1. No. 1. Hal. 57-66. https://doi.org/10.31575/jp.v1i1.9 
Marlius, D. (2016). Pengaruh Bauran Pemasaran Jasa Terhadap Minat Nasabah Dalam Menabung Pada Bank Nagari Cabang Muaralabuh. https://doi.org/10.31227/osf.io/vdqgx

Martika Ps, K., \& Wulandari Kusumadew. (2016). Analisis Pengaruh Bauran Pemasaran Terhadap Volume Penjualan Pada Pt . Hatten Bali Di Kota Denpasar. E-Jurnal Manajemen Unud, 5(5), 3080-3105.

Mayliza, R. (2019). Pengaruh Kesadaran Merek, Asosiasi Merek Dan Perception Of Quality Terhadap Keputusan Pembelian Hospital Bed Merek Paramout Di PT. Aga Medika Utama Padang (Studi Kasus Rumah Sakit Umum Kota Padang). https://doi.org/10.17605/OSF.IO/VYQ4E

Nurcahyo, F., \& Wahyuati, A. (2016). Pengaruh Bauran Pemasaran Terhadap Volume Penjualan Pada Restoran Mcdonald' S Delta Plaza Surabaya. Jurnal Ilmu Dan Riset Manajenmen, 5(4), 1-17.

Pristyo, M. (2013). Pengaruh Produk Dan Harga Terhadap Volume Penjualan Pada Ud. Eka Jaya Di Surabaya. E-Jurnal Kewirausahaan, 1(1), 27-37.

Salindeho, H. A. (2014). Pengaruh Saluran Distribusi Dan Harga Terhadap Peningkatan Volume Penjualan Pada Pt Fastrata Buana. Ilmu \& Riset Manajemen, 3(9), 1-15.

Srilenayati.(2007). Sejarah Dan Struktur Organisasi Pabrik Tahu Atb Padang. Pabrik Tahu Atb : Padang. 60 Mins.

Susanti, F., \& Gunawan, A. C. (2019). Pengaruh Bauran Promosi Dan Harga Terhadap Keputusan Pembelian Produk Kosmetik Maybelline Di Kota Padang. https://doi.org/10.31227/osf.io/npjqh

Susanti, F. (2015). Pengaruh Bauran Promosi Terhadap Keputusan Klien Dalam Memilih Radio Carano Sebagai Media Promosi Iklan. https://doi.org/10.31227/osf.io/b9ws7

Yuz, I., \& Widyaningrum, R. (2009). Pengaruh Kualitas Produk Terhadap Volume Penjualan Pada Home Industri Kripik Tempe " Abadi ” Singgahan Kecamatan Kartoharjo, 1-10 